\title{
ENHANCING ON-FARM CONSERVATION OF AGRO-BIODIVERSITY THROUGH COMMUNITY SEED BANK: AN EXPERIENCE OF WESTERN NEPAL
}

\author{
Shree Kumar Maharjan ${ }^{* 1}$, Assa Ram Gurung ${ }^{1}$ and B.R. Sthapit PhD ${ }^{2}$
}

\begin{abstract}
The community seed bank (CSB) is emerged as an effective rural institution at the community level to strengthen farmers' access to diversity of crop genetic resources as well as seeds that contribute to local food security for poor farmers and also to ensure the conservation of agro-biodiversity on-farm. This paper presents some evidences from the community of western Nepal to demonstrate that CSB is one of the options to conserve and use agro-biodiversity on farm. Biodiversity Conservation and Development Committees (BCDCs) and farmers have established six CSBs in western terai with the support of Agrobiodiversity component of Western Terai Landscape Complex Project (WTLCP-ABD) in Bardia (1 CSB), Kanchanpur (2 CSBs) and Kailali (3 CSBs) districts. These CSBs are functional with prearranged community developed mechanisms for collection, conservation, replication and distribution of seeds. Communities have collected and conserved 88 (Belwa), 77 (Beldandi), 99 (Gadariya), 78 (Masuriya), 76 (Patharaiya) and 82 (Shankarpur) number of accessions of different crops in CSBs. CSB enhanced farmer's seed system and strengthened social networks for exchange of seeds to cope with impacts of climatic adversity by providing immediate access to locally adapted germplasm as community based adaptation strategy. CSB is becoming a reliable local adaptation practice that minimizes the potential negative impacts of climate change in addition to accessibility, conservation and use of genetic resources in western terai of Nepal.
\end{abstract}

Key words: Community seed bank, genetic resources, local seed security, seed network, climate adversity.

\section{INTRODUCTION}

Agricultural biodiversity has been playing significant role in food security and sustainable livelihoods. Farmers have been conserving, maintaining and managing these resources for their sustenance. Nepal's rich agro-biodiversity is rapidly disappearing from farmers' fields over time and space due to induced human pressures and other climatic factors. With this disappearance of agro-biodiversity, global community recognized the importance of onfarm conservation (Regmi et.al., 2008). As agro-biodiversity is the backbone for the sustainable development of agriculture, food security and poverty alleviation in Nepal, both government and civil society organizations have prioritized to conserve, maintain and sustainable use of the available diversity on-farm. Role of local communities is key in maintaining and managing local genetic materials for food and nutrition security (Upadhyay et.al., 2008).

Community seed bank (CSB) is a contact point to access local seed and associated knowledge through mobilizing social, financial and human capital for community sensitization and conservation of agro-biodiversity. It is emerging as an effective community institution that strengthens farmers' capacities on collection, conservation, distribution and sustainable use of local crop genetic resources for food and agriculture in those areas, where rapid genetic erosion of traditional varieties is observed. In most of the cases, improved and exotic varieties replaced local crop genetic resources, thus narrowing

\footnotetext{
${ }^{1}$ Local Initiatives for Biodiversity Res.and Dev.(LIBIRD), GPO: 324, Gairapatan, Pokhara.

2 Bioversity International, New Delhi.
} 
the genetic base in agro-biodiversity and increasing the dependency of farmers to external sources for their seed requirements (FAO, 1997; Chaudhary et.al, 2004).

CSB approach was tested as an entry point to conserve, document, and manage the crop genetic resources in the community level; enable communities to access seeds and enhance their resources and knowledge (Majaju et. al., 2003). It also explores and transfers knowledge/information on endangered, unique and useful landraces to young generations and also develops local level conservation actions for the benefits of community. In this context, CSB intervention was integrated with the community farming systems in western terai landscapes of Nepal. Western Terai Landscape Complex Project (WTLCP) is a multipartner project designed to conserve and ensure the sustainable use of globally significant biodiversity in the western terai of Nepal.

Farmers and Biodiversity Conservation and Development Committees (BCDCs) have established six community seed banks (CSBs) in western Terai with technical support of Local Initiatives for Biodiversity, Research and Development (LI-BIRD) and financial support from GEF/UNDP. These CSBs are functional in Belwa VDC of Bardia district; Patharaiya VDC, Masuriya VDC and Gadariya VDC of Kailali district and Shankarpur VDC and Beldandi VDC of Kanchanpur district. Main aim of establishing CSB is to enhance farmers' accessibility to seeds at local level and maintain local seeds through strengthening social seed networks and also to promote community based conservation actions at household to community level (Regmi et.al., 2007).

\section{METHODOLOGY}

This paper is a result of the agro-biodiversity component in WTLCP implemented in western terai. For this paper, review of the literatures, series of consultative meetings with communities, awareness raising programs and diversity fairs 1 were organized to sensitize the farmers agree on scope and importance of local genetic resources (Regmi et. al., 2008). Germplasms displayed in these fairs were collected and conserved in community seed banks. So, review of diversity fair records and the CSB record books/community biodiversity registers (CBRs2) in the sites were conducted in the process of CSB formation for further characterization and evaluation with associated information documented in community biodiversity registers.

The information and data on accessions in CSBs were then tabulated, analyzed and presented in graphs. Leader and experienced farmers were identified with community consultation and key informant survey was conducted to understand to flow of accessions and related information within communities. Using this information, social seed networks were analyzed using net-draw software.

\section{RESULTS AND DISCUSSIONS}

\section{ENHANCED AVAILABILITY AND ACCESSIBILITY OF SEEDS FOR LOCAL SEED SECURITY}

Most of the subsistence-oriented farmers save their own seeds of staple crops to fulfill basic requirement of quality seeds. Farmers need seed because without viable seed the survival of their household becomes endangered. Seed saving after every harvest is a common practice in Nepal that ensures availability of quality seeds for next crop growing season. Farmers in western terai also save their own seeds. It is revealed that the main source of seeds for farmers was their own saved seeds (68 to 91\%) and also seed from neighbors and relatives (Baniya et. al., 2005, Shrestha et.al., 2064 B.S3.). Most farmers

1 Diversity fair = competitive exhibition of genetic materials, food products and their usages by communities.

$2 \mathrm{CBR}=$ participatory approach to inventorize genetic materials and knowledge base within community.

3 Bikram Sambat (Nepali year) 
have followed seed selection before and after crop harvest (Box-1). With this age-old practice, farmers are maintaining and conserving certain agro-biodiversity in their farms or home gardens that have utility values for their family needs and requirements. In this regard, every farmer is conserving and utilizing specific crop varieties having utility values (Shrestha et.al, 2008). Nevertheless, these farmers' practices and systems of seed storage and supply are increasingly coming under pressure (Lewis and Mulvany, 1997).

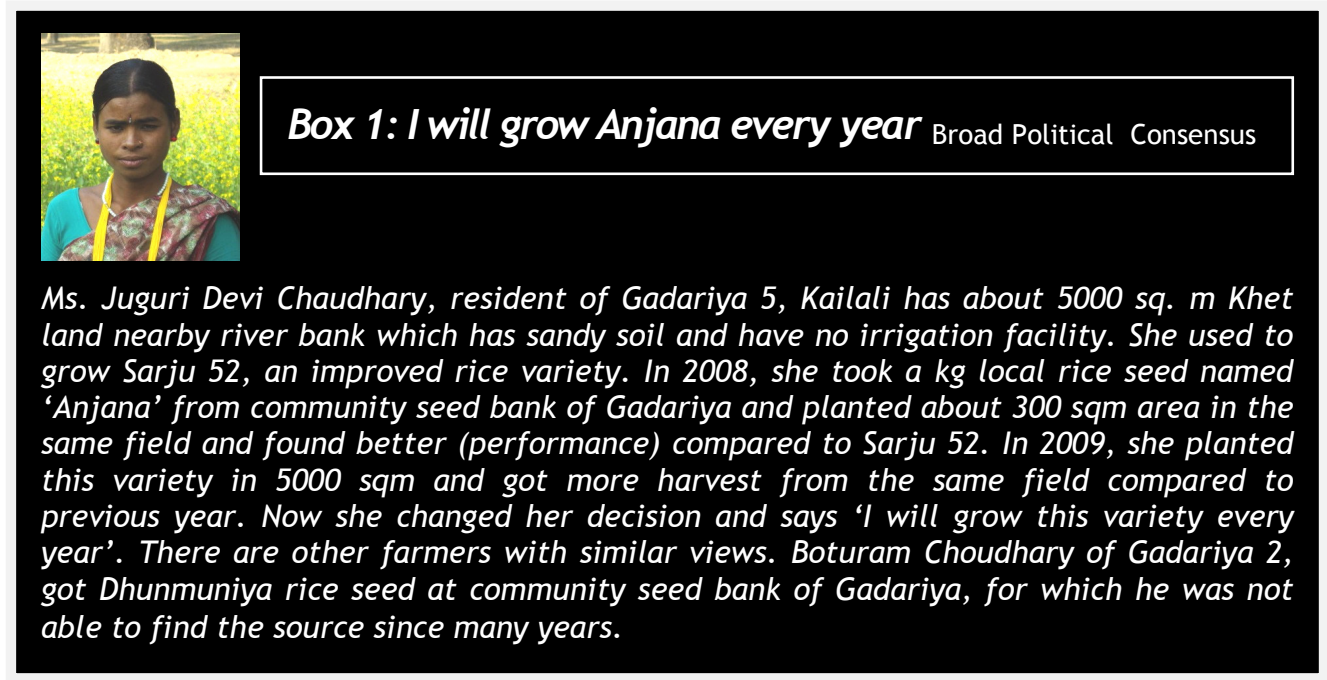

CSBs in western terai have collected seeds from farmers' fields, have conserved in seed banks and also distributed to the farmers in the community that made the rare landraces available to common ensuring seed security in local context (Shrestha et.al., 2008). It also ensures conservation and accessibility of seeds of traditional varieties, in addition to commercialized improved crop seeds. Cultivation of improved varieties in community based seed production (CBSP1) has linked with conservation, CBSP farmers group has to conserved at least one traditional variety, which is mentioned in the rules developed by the community to ensure successful operation of CSB. Table-1 below provides the information about the landraces conserved in community seed banks and quantity of seeds of local and improved varieties accessed by the farmers across the CSB sites in 2009 and Table-2 presents the number of male and female beneficiaries (impact groups) from the seed banks in the VDCs in 2009.

Table 1: Conservation and access of seeds from community seed banks in 2009

\begin{tabular}{lccccccc}
\hline \multirow{2}{*}{ Number and quantity of seeds in CSB } & \multicolumn{7}{c}{ Agrobiodiversity Project Sites in WTLCP } \\
\cline { 2 - 8 } & Gadariya & Masuriya & Pathraiya & Beldandi & Shankarpur & Belawa & Total \\
\hline No. of local crop varieties conserved & 60 & 66 & 53 & 62 & 61 & 61 & 363 \\
Qty. of local seeds accessed (kg) & 550 & 132 & 212 & 310 & 305 & 183 & 1262 \\
Qty. of improved seeds accessed (kg) & 4900 & 6900 & 8900 & 6700 & 8900 & 8400 & 44700 \\
\hline
\end{tabular}

Resource poor farmers have relatively less access to available resources (seeds and other agricultural inputs) primarily due to low purchasing power. In this sense, establishment of CSB and participation of resource-poor farmers in the program(s) definitely enhanced their

1 CBSP = production and marketing of potential crop species at community level for community benefits. 
access to genetic resources and information, and empowered them through capacity building training activities implemented in the project. Out of total beneficiaries, around $25-30 \%$ of the farmers are resource poor who are actively participating in CSB activities and getting benefits from CSB across the VDCs in the agro-biodiversity component in WTLCP. Farmers are also operating a saving and credit in community biodiversity management fund (CBM fund) from where resource poor farmers can get loan for income generating activities that ultimately helps in social cohesiveness among members and provide livelihood options for those poor. They have made a rule that each member getting loan should have to conserve/grow at least one landrace in his/her home garden (Shrestha et. al., 2005).

\section{ENHANCED CONSERVATION AND USE OF CROP GENETIC RESOURCES}

Since WTLCP is rich in forest and agricultural biodiversity (Regmi et.al., 2007), a large number of cultivated and uncultivated crops, fruits, vegetables, and herbs including rice landraces (shyamjira, kanakjira, raimanuwa) are conserved in community seed banks. While comparing the yearly records of the seed bank registers across the CSBs, numbers of seeds conserved and accessed in CSBs are increasing over the years, and more farmers are getting benefits out of it, which is good indication of success in western terai landscapes (Table-2). These farmers are directly involving in seed collection, multiplication, distribution and seed exchange activities.

Table 2: Total Number of beneficiaries from CSB in western terai landscapes

\begin{tabular}{llllllll}
\hline \multirow{2}{*}{$\begin{array}{l}\text { Number of } \\
\text { beneficiaries* }\end{array}$} & \multicolumn{7}{c}{ Agrobiodiversity Project Sites in WTLCP } \\
\cline { 2 - 7 } & Gadariya & Masuriya & $\begin{array}{l}\text { Pathraiy } \\
\text { a }\end{array}$ & Beldandi & $\begin{array}{l}\text { Shankar } \\
\text { pur }\end{array}$ & Belawa & Total \\
\hline Male & 169 & 206 & 142 & 127 & 125 & 112 & 881 \\
Female & 333 & 233 & 194 & 126 & 121 & 163 & 1170 \\
Total & 502 & 439 & 336 & 253 & 246 & 175 & 1951 \\
\hline
\end{tabular}

\section{Number of accession and/or varieties conserved in community seed banks in WTLCP}

No. of accessions/varieties

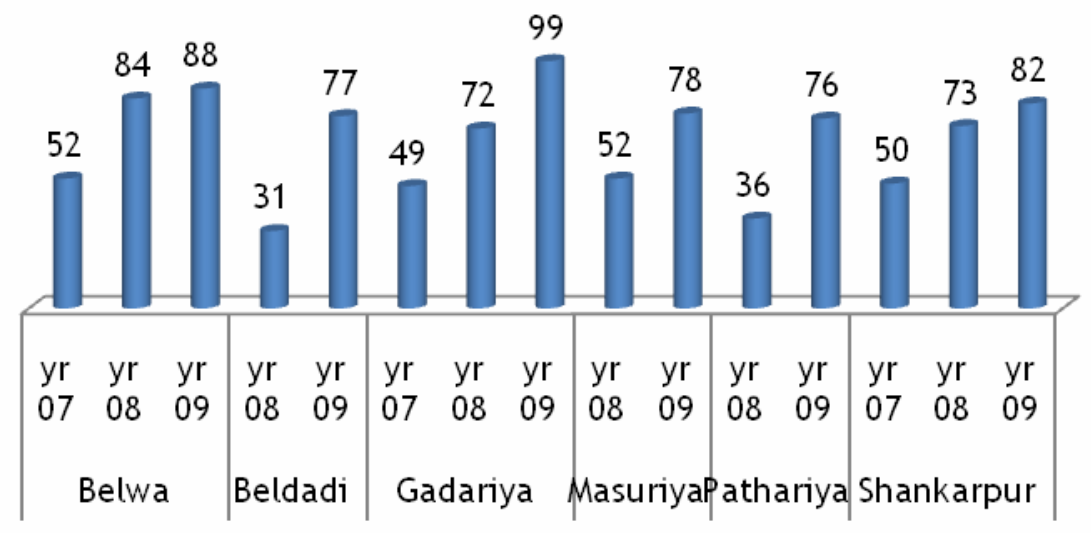

Fig.1: Number of accession and/or varieties conserved in community seed banks in WTLCP

Despite the rapid changes in many rural communities, seed banks are an important method of seed supply and seed multiplication for small-scale farmers (Lewis and Mulvany, 1997). For example, total number of accessions conserved in Belawa was only 52 in starting year 
(2007) that increased to 88 in 2009 including both local landraces (61) and improved varieties (27) (Fig.1). The project has oriented farmers to follow mechanism to regenerate and distribute the seeds collected and conserved in CSB (Table 3). They have established diversity blocks for both local and improved varieties, in which they grow the collected crops from which later seeds are collected and conserved in bank and managed in a community managed Dedhi system (system of returning one and half of the seeds distributed to the farmers). For those varieties and landraces having more demand in the community, farmers followed community based seed production. Radha-4, Hardinath-1, and Judi-582 of rice; Gautam, Bhrikuti, NL-297 and BL-2800 of wheat; and Khajura-1, Khajura-2, ILL-7723, ILL-7982 and ILL-6829 of lentil were cultivated for seed production in 2009, which later conserved in CSB and sold to the farmers within respective VDC and farmers of surrounding VDCs.

Table 3: Total Number of accessions and varieties conserved in CSB in western Terai Landscapes

\begin{tabular}{|c|c|c|c|c|c|c|c|c|c|c|c|c|c|c|c|}
\hline \multirow[t]{2}{*}{ Seeds in CSB } & \multicolumn{3}{|c|}{ Belawa (n) } & \multicolumn{2}{|c|}{ Beldadi (n) } & \multicolumn{3}{|c|}{ Gadariya (n) } & \multicolumn{2}{|c|}{ Masuriya $(\mathrm{n})$} & \multicolumn{2}{|c|}{ Pathariya (n) } & \multicolumn{3}{|c|}{ Shankarpur (n) } \\
\hline & 2007 & 2008 & 2009 & 2008 & 2009 & 2007 & 2008 & 32009 & 92008 & 2009 & 2008 & 2009 & 2007 & 2008 & 2009 \\
\hline \multicolumn{16}{|l|}{ Cereals } \\
\hline Rice & 18 & 30 & 33 & 8 & 38 & 18 & 30 & 36 & 19 & 38 & 11 & 38 & 9 & 27 & 36 \\
\hline Maize & 2 & 3 & 4 & 3 & 3 & 3 & 3 & 3 & 3 & 3 & 3 & 3 & 3 & 3 & 3 \\
\hline Millets & - & - & 3 & - & 3 & - & - & 1 & 4 & 4 & - & 2 & - & - & 1 \\
\hline \multicolumn{16}{|l|}{ Oil seeds } \\
\hline Mustard & 2 & 4 & 6 & - & 6 & - & 6 & 6 & - & 5 & - & 5 & - & 5 & 6 \\
\hline Til & - & 2 & 3 & 2 & 3 & - & 2 & 4 & - & 3 & - & 3 & - & 2 & 3 \\
\hline \multicolumn{16}{|c|}{ Pulses and vegetables } \\
\hline Soybean & 4 & 4 & 4 & 4 & 4 & 4 & 4 & 4 & 4 & 4 & 4 & 4 & 4 & 4 & 4 \\
\hline Peas & 2 & 2 & 3 & 2 & 2 & 2 & 2 & 3 & 2 & 3 & 2 & 2 & 2 & 2 & 3 \\
\hline Beans & 1 & 5 & 14 & 4 & 5 & 5 & 6 & 12 & 3 & 11 & 4 & 8 & 2 & 4 & 11 \\
\hline Cowpea & - & 12 & 13 & - & - & - & 4 & 11 & 3 & - & 3 & - & 4 & - & 10 \\
\hline Broad Beans & - & 1 & 2 & 4 & 4 & 4 & 1 & 1 & 1 & 1 & 1 & 1 & 1 & 1 & 1 \\
\hline Sponge gourd & 8 & 10 & - & 2 & 5 & 5 & 5 & 7 & 7 & - & 3 & 4 & 12 & 13 & - \\
\hline Bottle gourd & 7 & 7 & - & - & - & 4 & 5 & 3 & 4 & 2 & 3 & 2 & 9 & 9 & - \\
\hline Black gram & 2 & 2 & 2 & 2 & 2 & 2 & 2 & 2 & 2 & 2 & 2 & 2 & 2 & 2 & 2 \\
\hline Rice bean & 1 & 2 & 1 & - & 2 & - & 2 & 2 & - & 2 & - & 2 & - & 1 & 2 \\
\hline Pumpkin & 5 & - & - & - & - & 2 & - & 4 & - & - & - & - & 2 & - & - \\
\hline
\end{tabular}

CSB has also explored participatory germplasm exchange in addition to establishment of diversity blocks of those landraces in western terai landscapes for improved access and regeneration of landraces. This approach has strengthened farmers' seed system with farmer-to-farmer seed exchange. In this way the rare and threatened varieties has migrated and colonized in a specific niche to spread further as theory of meta-population suggests (Freckleton and Watkinson, 2002). Women has played important role in CSB with active participation in seed exchange programme in western terai. They have distributed landraces grown in their home gardens to their neighbors, relatives and other farmers. With involvement of women in CSB and related trainings and exposure visits, their roles are ever increasing for conservation of landraces, knowledge sharing and joint initiatives for knowledge and seed exchange among community for enhancing social cohesion and livelihood options at community level. 


\section{ENHANCED SEED NETWORKS IN LANDSCAPE TO DEAL WITH CLIMATE ADVERSITY}

Agriculture in western terai landscapes is vulnerable, mostly affected by severe drought and flood due to uncertainty of rainfall, and also suffers due to lack of reliable sources of seeds, fertilizers and other agricultural inputs. Unavailability of value addition options for more benefits from landraces, lack of quality seeds, accessibility and market, agricultural inputs, irrigation and technical backstopping have led to loss of traditional crop landraces from farmers fields. This not only has limited farmer's livelihood options, but also makes them more vulnerable to changing climate, as landraces can withstand more climatic stresses than modern varieties. However, farmers are continuing to cultivate local cultivars in both marginal areas and high production potential systems under traditional farming systems (Upadhyay and Subedi, 2003). In such situation, CSB is gradually coming up to deal with conservation, improve access to seeds locally and also serve as drought coping and management strategy at community level.

Farmers are maintaining these local crop diversities through informal flow of seeds and planting materials within the communities and across the landscapes since many generations (LI-BIRD, unpublished). These systems of seed flows are functional through exchange between seed to seed, or grain for seed and other planting materials on barter basis or as gift or purchase among farmers.

In WTLCP project sites, farmers' seed systems and their social networks are playing important role in conserving the local crop diversity. Existence of interconnected and complex seed network in community can play significant role in crop diversity maintenance such as seeds lost from one community can be recovered from other cluster of community members in the landscape. In absence of such connection, CSB and participatory germplasm exchange are good intervention for promoting on-farm management and prepare community members to cope with climate change adversity. Tilki, rice landrace grown in the field of Ram Prasad Rana, a farmer in Shankarpur VDC, Kanchanpur became known as a flood tolerant landrace after occurrence of devastating flood in 2008. Seeing the fact, farmers demanded seeds of Tilki for the lowland fields (LI-BIRD, unpublished). CSB in Shankarpur collected that landrace, multiplied seeds and distributed the seeds to the farmers. As a community based adaptation strategy, immediate intervention on strengthening the local seed systems under CSB was initiated. The community seed banks are found as reliable means to increase the access to seeds and safeguard the crop genetic materials at local level. The project has further developed a mechanism like participatory seed exchange to initiate exchange of seeds within and outside community therefore the network is expanded in the landscape.

\section{CONCLUSIONS}

On farm management of agricultural biodiversity is a contributor to sustainable livelihoods of rural and marginal farming communities. Community seed banking has been very effective community led approach in conserving the rare and threatened but socioculturally important species. CSB intervention is recognized as an important strategy to reduce the effects of seed insufficiency among small-holder farmers in western terai of Nepal. Availability of diverse (local and improved) accessions and germplasms in the CSB obviously enhances conservation and seed accessibility for food and agriculture even during the years with climatic stresses.

CSB has conserved and enhanced seed availability and accessibility to the farming community which has (that also) reduced dependency of the farmers to outer sources for seeds. This ultimately supports the sustainable livelihoods of rural and marginal farming communities, as it is regarded as novel and innovative strategy to conserve locally threatened and globally important crop genetic resources in a western terai landscapes. CSB is a good practice to conserve, re-generate and multiply the crop seeds within 
community. Initially community started to conserve locally available genetic resources in CSB but now they are also realizing the importance to CSB as seeds conserved in it (that) reduces their dependency towards outer sources. Similarly, they came to know that local landraces are more tolerant to changing climatic context.

\section{ACKNOWLEDGEMENT}

The authors would like to acknowledge all farmers in Belwa, Patharaiya, Gadariya, Masuriya, Beldandi and Shankarpur VDCs of western terai landscapes for their cooperation, active participation and providing information related to community seed banks established in their VDCs. The authors also express their gratitude to Ashok Gurung, Ek Raj Sigdel, Basanta Rajgaiya and Bhai Kaji Sapkota for their supports in field works.

\section{REFERENCES}

Baniya, B. K., R. K. Tiwari, P. Chaudhary, S. K. Shrestha and P. R. Tiwari, 2005. Planting materials seed systems of finger millets, rice, and taro in Jumla, Kaski and Bara districts of Nepal. Nepal Agriculture Research Journal, 6:39-48.

Chaudhary, P., D. Gauchan, R. B. Rana, B. R. Sthapit and D. I. Jarvis, 2004. Potential loss of rice landraces from terai community in Nepal: a case study from Kachorwa, Bara. Plant Genetic Resources Newsletter,vol.137, pp.14-21

FAO, 1997. The State of the World's Plant Genetic Resources for Food and Agriculture. Rome: Food and Agriculture Organization of the United Nations.

Freckleton, R. P. and A. R. Watkinson, 2002. Large-scale spatial dynamics of plants: Meta-populations, regional ensembles and patchy populations, Essay Review, Journal of Ecology, 90:419-434.

Lewis, V. and P. M. Mulvany, 1997. A typology of community seed banks. Natural Resources Institute (NRI), University of Greenwich, Central Avenue and Intermediate Technology Development Group, Myson House, United Kingdom. NRI Project A0595.

LI-BIRD, (unpublished). Climate change and agro-biodiversity in Nepal: Opportunities to include agrobiodiversity maintenance to support Nepal's national adaptation programme of action (NAPA), a report submitted for Platform for Agro-biodiversity Research in collaboration with FAO and Bioversity International.

Majaju, C., F. Jinhanga and E. Rusike, 2003. Community seed banks for semi-arid agriculture Zimbabwe, conservation and sustainable use of agricultural biodiversity: a source book. CIPUPWARD in partnership with GTZ GmbH, IDRC, IPGRI and SEARICE. pp 294-301

Regmi, B. R., B. R. Sthapit, M. P. Upadhyay and P. Shrestha, 2008. Mainstreaming good practices of onfarm conservation in context of Western Terai Landscape Complex Project (WTLCP). In: B. R. Sthapit, D. Gauchan, A. Subedi and D. Jarvis (eds.), On-farm management of agricultural biodiversity in Nepal: lessons learned, Proceeding of the national symposium 18-19 July 2006, Kathmandu, Nepal, pp.211-217. NARC/LI-BIRD/IDRC, ISBN: 978-92-9043-793-2.

Regmi, B. R., P. Shrestha, A. Adhikari, A. R. Khanal, I. Poudel, H. Poudel and B. P. Mahato, 2007. Western Terai Landscape Complex Project agrobiodiversity component: site selection report. Local Initiatives for Biodiversity, Research and Development (LI-BIRD), Pokhara, Nepal ISSN 1561$154 x$.

Shrestha, P., A. Subedi, D. Rijal, D. Singh, B. R. Sthapit and M. P. Upadhyay, 2005. Enhancing local seed security and on-farm conservation through community seed bank in Bara district of Nepal. In: B. R. Sthapit, M. P. Upadhyay, P. K. Shrestha and D. I. Jarvis (eds.), On-farm conservation of agricultural biodiversity in Nepal. Vol.2, Managing diversity and promoting its benefits, Proceedings of the second national workshop, 25-27 August 2004, Nagarkot, Kathmandu, pp.7076. IPGRI, ISBN-10:92-9043-696-4.

Shrestha, P., A. Subedi, R. K. Yadav, R. N. Yadav, and M. N. Yadav, 2007 (2064 BS). Purano biu: naya samrakshan paddati (Old seeds: new conservation strategy). Local Initiatives for Biodiversity 
Research and Development (LI-BIRD), Pokhara and Agricultural Development and Conservation Society (ADCS), Kachorwa, Bara.

Shrestha, P., B. R. Sthapit, A. Subedi, D. Poudel, P. Shrestha, M. P. Upadhyay and B. K. Joshi, 2008. Community seed bank: good practice for on-farm conservation of agricultural biodiversity. In: B. R. Sthapit, D. Gauchan, A. Subedi, and D. I. Jarvis (eds.), On-farm management of agricultural biodiversity in Nepal: Lessons learned, Proceedings of the national symposium, 18-19 July 2006, Kathmandu, Nepal, pp.112-120. NARC/LI-BIRD/IDRC/SDC, ISBN: 978-92-9043-793-2.

Upadhyay, M. P. and A. Subedi, 2003. Good practices for managing in-situ conservation of agrobiodiversity on-farm. In: B. R. Sthapit, M. P. Upadhyay, A. Subedi, and B. K. Joshi (eds.), On-farm management of agricultural biodiversity in Nepal, Proceedings of National workshop, 24-26 April 2001. Lumle, Nepal. pp.271-276. NARC/LI-BIRD/IPGRI.

Upadhyay, M. P., D. Gauchan, P. Shrestha and B. R. Sthapit, 2008. Institutionalization of the policy and practices of in-situ conservation of agricultural biodiversity in national research and development in Nepal. In: B. R. Sthapit, D. Gauchan, A. Subedi, and D.I. Jarvis (eds.), On-farm management of agricultural biodiversity in Nepal: Lessons learned, Proceedings of the national symposium, 18-19 July 2006, Kathmandu, Nepal, pp.19-28. NARC/LI-BIRD/IDRC/SDC. ISBN: 978-92-9043-793-2, 